\title{
空気力学に基づくトンボのビジュアルシミュレーション
}

\author{
朱 朝江 村岡 一信 水野 尚 \\ 東北工業大学
}

\begin{abstract}
概要 トンボは季節を感じさせる身近な存在の一つであり,コンピュータグラフィックスによるトンボの表現 は, 景観シミュレーションやバーチャルリアリティなどの季節感を向上させる要素として期待できる.本論文 では,空気力学に基づくトンボの飛翔モデルを提案する.本モデルでは,翅のはばたきによる力を考慮してト ンボをリアルタイムで飛翔させる . トンボの飛翔の特徵である急上昇, 急停止, ホバリング, 急旋回などを行 うことができ，さらに，空間に制御点を配置することでトンボの飛翔経路を容易に定めることができる． キーワード : リアルタイム , アニメーション , はばたき , 昆虫 , 空気力学
\end{abstract}

\section{Visual Simulation of Dragonflies Based on Aerodynamics}

\author{
Chaojiang Zhu \\ Kazunobu Muraoka \\ Hisashi Mizuno \\ zhugj@smail.tohtech.ac.jp \\ muraoka@tohtech.ac.jp \\ hmizuno@tohtech.ac.jp \\ Tohoku Institute of Technology
}

\begin{abstract}
A dragonfly is a familiar insect by which the sense of season can be shown. The expression of a dragonfly by CG can be expected as an element improving the sense of season in landscape simulation, virtual reality ,etc .This paper proposes the flight model of a dragonfly based on aerodynamics .In this model ,a dragonfly can be made to fly in real time considering the force caused by the flapping of the wings ,performing flight characteristics including steep rise ,sudden stop , hover and rapid turn .Furthermore, the flight route of a dragonfly can be easily established depending on the control-points placed in the space .
\end{abstract}

Keywords: real-time, animation, flapping flight, insect, aerodynamics

\section{1.はじめに}

バーチャルリアリティや景観シミュレーションな どのリアリティ向上のため, コンピュータグラフィ ックス(CG)による自然物や自然現象のリアルな表現 か期待されている.本論文では昆虫のトンボを取り 上げ, 兴のリアルタイム表示を目的とした , ビジュ アルシミュレーション法を提案する .

飛翔する昆虫のCG に関するこれまでの研究には， 雨川ら[1]による魅力の場による蝶の飛翔に関する研 究や, 安齋ら[2]による蝶の飛翔モデルがあるが, 卜 ンボについての研究は見当たらない．

飛翔生物のC Gには，はばたきによる力を考慮し ないもの[1,3]と考慮したもの[2,4,5]とがある . 前者 は計算量は少ないが，はばたきと胴体の移動との間 に因果関係かなく，はばたきの動作を注意深く設計 しなければ不自然となる . 後者は, 計算量は増加す
るが, はばたきと同体の移動との関係はより自然と なる .

このため, 本手法では後者の立場をとる . はばた きの力を考慮した B.Ramakrishnananda ら[5]の鳥 のモデルで , 胴体のピッチング運動を翼の動作か ら求めているが, 前進しか考慮されておらず, 左右 へ旋回することができない . 一方, 筆者らの一部が 提案した蝶のモデル[2]や鳥のモデル[4]では左右へ の旋回力行え，制御点によって飛翔経路を制御する ことかできる.本手法では, 蝶のモデルで用いた手 法をトンボへ拡張する.蝶のモデルでは前翅と後翅 を1枚の翅て近似しているため，トンボのように前 翅と後翅力独立して動作する飛翔昆虫は表現するこ とができない，また，飛翔制御では，イチモンジセ セリなど，やや飛翔速度が速い蝶では制御点を一度 で通過できない場合があるという問題があつた。 . 
ンボは昆虫の中でも飛翔能力が高いことて知られ， 高速な直線飛翔や急降下, 急上昇, 急停止やホバリ ングなど蝶より複雑な飛翔力行える。このため，本 論文では, トンボの表現に向いた飛翔モデルと飛翔 経路制御の拡張法について示す .なお，本手法は卜 ンボのリアルタイムC Gを目的としており，翅のは ばたきによる力を厳密に解析するためのものではな いことを断っておく .

\section{2. 実際のトンボの特徵}

ここでは，表現対象である実際のトンボにつて， 文献 $[6,7,8,9,10,11,12,13]$ よりまとめる .

\section{1 トンボのはばたき機構}

図 1 はトンボと蜂のはばたき機構を示したもので ある.多くの昆虫は(b)のように゙ 間接筋”によるは ばたき機構であり，翅はてこのように側板の支点に 支えられ，根元の柄が脊板に連結されている . 炎の ため左右前後の翅は同時にはばたく．トンボは(a)の ように“直接筋”によるはばたき機構であり，翅の 根元のてこの柄部分が，支点の両側で午れぞれ直接 打ち上け打ち下ろし用の筋肉に連結されている. 光 のため4枚の翅を光れ元れ独立してはばたかせるこ とができ, 飛羚㴰力は高い .

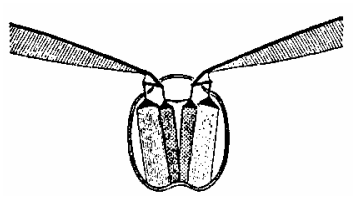

I) 打ち上げ

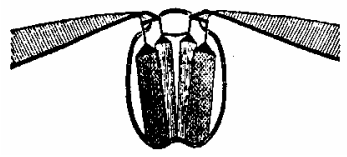

II ) 打ち下ろし

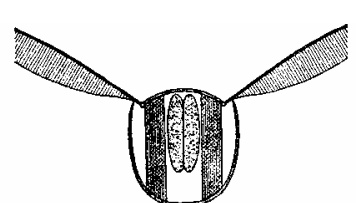

I) 打ち上げ

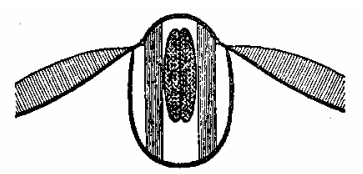

II) 打ち下ろし

(b) 蜂 (a) トンボ

図 1 昆虫のはばたき機構[8]

\section{2 トンボの翅の動作と飛翔の特徵}

トンボは翅を上下にはばたかせるフラッピング軍 動, 翅の前縁を回転軸として, 翅の後縁を上下させ るフェザリング運動, ストローク面の角度を変化さ せる運動（ストローク運動と呼ぶことにする）を行 っている . ストローク面とは , 図 2 に示すように翅 の先端の移動軌跡力乗る面のことである . トンボは 翅の付け根の部分を回転させてストローク面を傾け， 推力の方向を変えることで, 急停止, 急旋回 , ホバ リングなどの複杂倠な飛翔を行える。

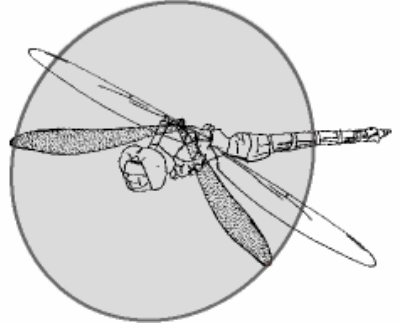

図2 ストローク面

\section{3 トンボの飛翔の特徵}

図 3 に示すように, 蝶などの昆蚛前後の翅を同 時にはばたかせるため，胴体が上下動するのに対し， トンボは前と後の翅を互い違いに動作させるため胴 体の上下動は少ない．これにより直線的で高速な飛 翔力行える．また，市販のトンボに関するビデオや 著者らの観察では, 直線的に飛翔する距離はあまり 長くなく，頻繁に方向を変えるようすが見られた.

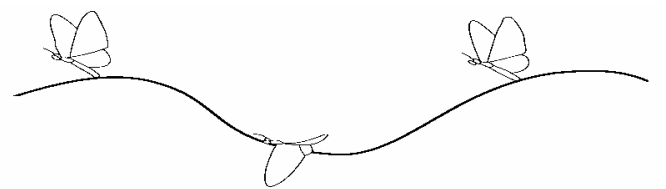

(a) 蝶

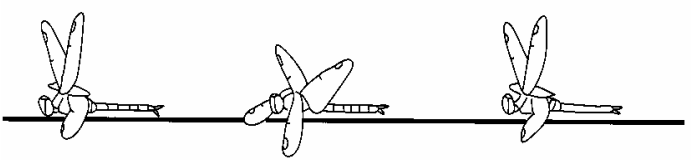

(b) トンボ

図３蝶とトンボの飛翔の比較[6]

\section{4 トンボの止まり方の特徴}

トンボはいったん飛び出すとあまり止まらない 「飛翔型」と, 止まっている比率の高い「静止型」 の二つに分けられる . トンボが止まるとき, 飛翔型 は枝先などを掴んでゔら下がって止まる「ゔら下が り型」が多く, 静止型は地面にうつっ池に止まる「う つふ池型」が多い (図 4 参照).いずれのトンボも， 夜間眠る時はぶら下がり型である。

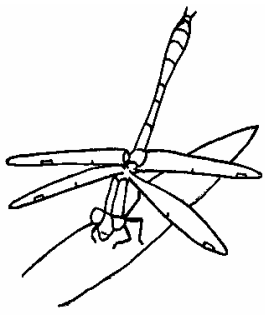

(a)うつふ池型

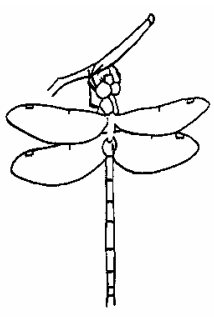

(b)ぶららがり型
図4 トンボの止まり[6] 


\section{3.トンボの飛翔モデル}

ここでは, 2.で示したトンボの飛翔の特徵を表現 するための飛翔モデルを示す .

\section{1 基本的な飛翔モデル}

ここで, 文献[2]の翅のはばたきによる力を求める モデルを簡単に示す.翅は一枚の薄い板であると仮 定し，乥の板に当たる空気の流れをべクトル $V_{r}$ で表 す. 翅には揚力 $L$ と抗力 $D$ 慟き，翅に作用する力 Fは次式で表される (図5参照).

$$
F=L+D
$$

揚力 $L$ と抗力 $D$ の大きさは次式て求められる[4].

$$
\begin{aligned}
& L=\frac{1}{2} \rho V_{r}{ }^{2} S C_{l}(\mathbf{a}) \\
& D=\frac{1}{2} \rho V_{r}{ }^{2} S C_{d}(\mathbf{a})
\end{aligned}
$$

ここで，

$\rho:$ 空気密度, $S:$ 翅の面積

$V_{r}$ ：翅に対する空気流の相対速度 $\left|V_{r}\right|$

$a ：$ 空気力学的迎角

$C_{l}: \quad$ a の関数で表された揚力係数

$C_{d}: \quad$ a の関数て表された抗力係数

である.空気力学的迎角aは, ベクトル $V_{r}$ と翅のな す角であり，空気流力楜の下面から当たる状態を正 值 , 上面から当たる場合を負值とする .

なお，本論文では $C_{l} ， C_{d}$ の関数として文献[7]を 参考に, 图6に示す関数を仮定した。

翅は，翅の付け根を通り，前後方向へ延びる軸を 回転軸としたフラッピング運動 (図 7(a)) と, 翅の

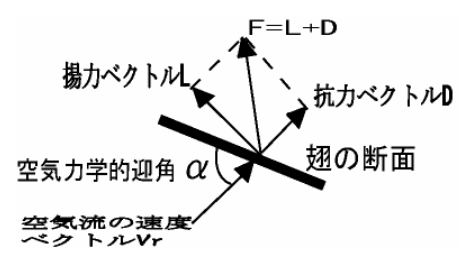

図 5 翅に作用する力

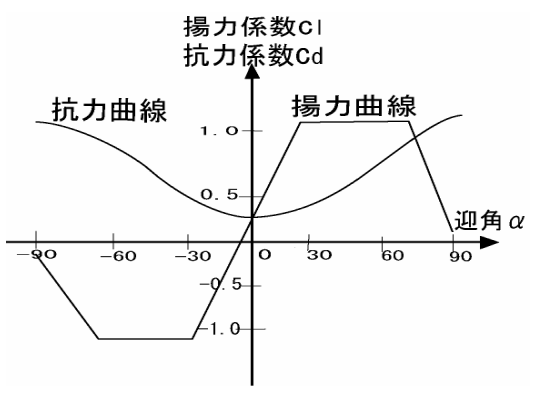

図 6 揚力抗力特性関数
前縁に平行な直線を回転軸とするフェザリング運動 (図 7(b)) を行う .

図 8 に, 本手法で用いたフラッピング角およびフ エザリング角のはばたき 1 周期分のグラフを示す . これらは 文献[7]の測定データを参考にして定めた 。

トンボガ速度べクトル Vて飛び, 翅のはばたき速 度ベクトルが $V_{n} の と き$ 相対空気流べクトル $V_{r}$ は次 式で表される (図9参照).

$$
V_{r}=-\left(V+V_{w}\right)
$$

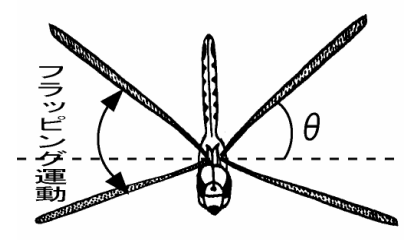

(a) フラッピング軍動

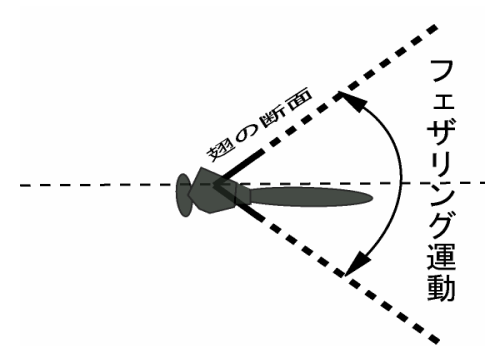

(b) フェザリング軍動

図 7 翅の基本的な運動

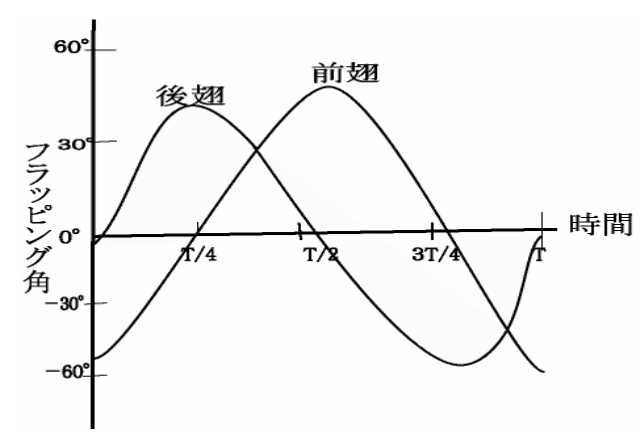

(a) フラッピング

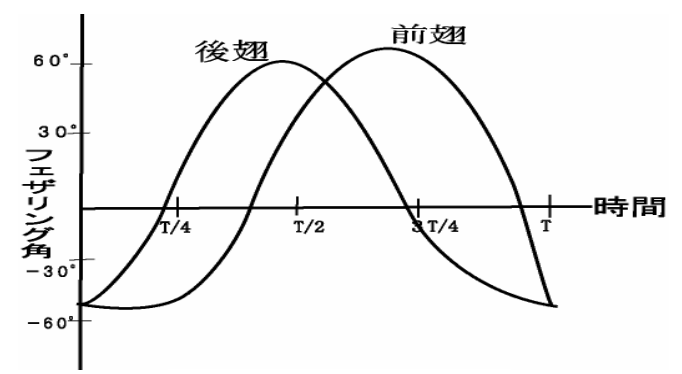

(b) フェザリング

图 8 一周期分のフラッピングとフェザリング角 


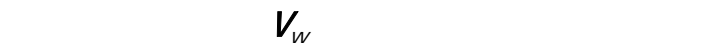
くべクトルであるため, 翅全体に作用する力は図 10(a)に示すように翅の付け根から先端までの各位 置における力の積分として求めなければならないが， 計算量削減のため翅の全体に作用する力の平均と同 等の力か作用するような点 $\mathrm{P}$ 力辻傓の付け根から翅の 先端の間にあると仮定し, 兴の速度べクトルをはば たきの力の計算に用いる(図 10(b)参照) .

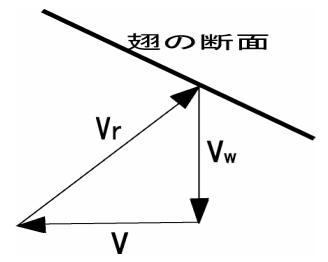

図 9 翅に対する空気流の相対速度
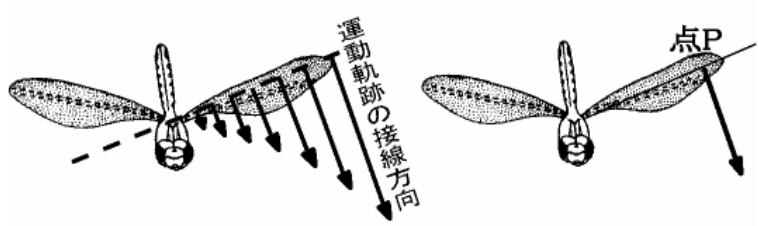

(a) 翅に作用する力の分布

(b) 平均と同じ力の点 $\mathrm{P}$

図 10 翅に作用する力の近似

\section{2 翅の動作}

トンボの翅の動作は ,3.1で述べたフラッピング運 動とフェザリング運動にストローク運動を加えた動 作とする $77,15,16]$.

翅がフラッピングするときのストローク面と体の 長軸の間の角度をストローク面角度と呼ぶことにす る (図 11 参照) . ストローク運動はストローク面角 度を変更する動作である。

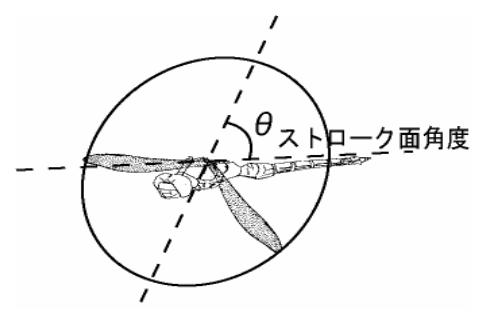

図 11 ストローク面角度の制御

\section{3 前翅の後翅への影響の考慮}

3.1 のモデルては，翅と翅との相互作用などが考慮 されていないため，はばたきによる力が不足する $[8,15,16]$. トンボでは前翅がくる空気の流れ (誘 導流）の中を後翅が通過することによる影響を考慮 しなければならない (図12 参照)．なお，後翅の誘

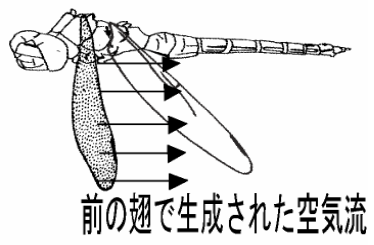

図 12 前翅の誘導流

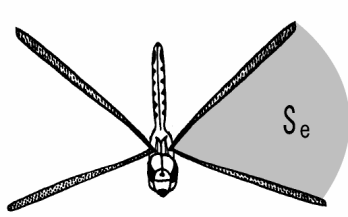

図 13 前翅のはばたきのストローク面の面積

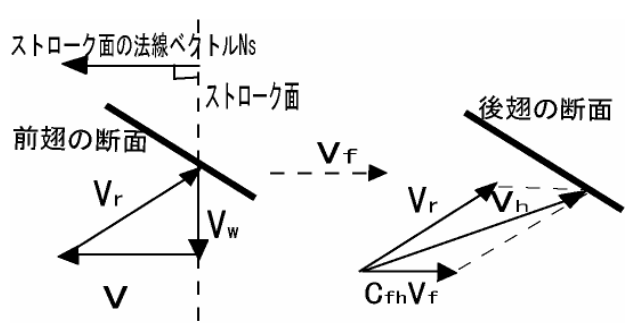

図 14 前翅の気流の影響を受ける後翅

導流の前翅への影響は小さいため[7] , 本モデルでは 前翅の誘導流のみを考慮する。

誘導流の計算には Azuma ら[7]力緩慢上昇する卜 ンボの飛翔の解析に用いた運動量理論を用いる . 文 献[7,14]の運動量理論より，前翅かははばたくことによ る誘導流の速度 $V_{f}$ は式(5)で与えられる .ただし， 流れの方向はストローク面に対して垂直と仮定する．

$$
V_{f}=-\frac{V}{2}+\sqrt{\frac{T}{2 \rho S_{e}}+\left(\frac{V}{2}\right)^{2}}
$$

ここで，Seは前翅のはばたきのストローク面の面 積 (図 13 参照)， $V$ はトンボの速度,$T$ は前翅のは ばたきによる推進力であり，次式で表される。

$$
T=N \cdot F
$$

ここで,“・”は内積，Nはストローク面の法線べ クトル， $F$ は前翅がはばたくことにより得られる力 のベクトルて式(1)で求められる.

後翅に対する相対的な空気流の速度ベクトルV $V_{h}$ は 次式て球められるものとする. (図 14 参照)

$$
V_{h}=V_{r}+C_{f h} V_{f}
$$

ここで，V$V_{f}$ は前翅のはばたきの誘導流の速度べク トル , $C_{f h}$ は誘導流力後翅におよぼす影響の程度を示 
し0〜1である。

後翅の揚力と抗力は， $V_{r} を V_{h}$ として(2)，(3)式で 求められる.

4枚の翅によって得られた力は, 簡単のためすべ てトンボの重心に作用させるものとし，このとき， トンボの運動方程式は次式で表される。

$$
\begin{aligned}
& F(t)=M a(t) \\
& F(t)=F_{f L}(t)+F_{f A}(t)+F_{h L}(t)+F_{h A}(t)+G \\
& F_{f L}(t)=L_{f L}(t)+D_{L L}(t) \\
& F_{f R}(t)=L_{f R}(t)+D_{R}(t) \\
& F_{h L}(t)=L_{h L}(t)+D_{h L}(t) \\
& F_{h A}(t)=L_{h A}(t)+D_{h A}(t) \\
& \approx \text { ご }, \quad \\
& M: \quad \text { トンボの質量 }
\end{aligned}
$$

$F(t): \quad$ 重心にかかる翅のはばたきによる力

$F_{f L}(t)$ ：左前翅に作用する力

$F_{f R}(t)$ ： 右前翅に作用する力

$F_{h L}(t)$ ：左後翅に作用する力

$F_{h R}(t)$ ： 右後翅に作用する力

$L_{f L}(t)$ ：左前翅に作用する揚力

$L_{f R}(t)$ ：右前翅に作用する揚力

$L_{h L}(t)$ ：左後翅に作用する揚力

$L_{h R}(t)$ ：右後翅に作用する揚力

$D_{L}(t)$ ：左前翅に作用する抗力

$D_{R}(t)$ ：右前翅に作用する抗力

$D_{L}(t)$ ：左後翅に作用する抗力

$D_{R R}(t)$ ：右後翅に作用する抗力

$a(t):$ 加速度ベクトル

$G: \quad$ 重力

$t: \quad$ 時刻

である。

なお，本モデルでは胴体にかかる空気抵抗や浮力 は, 翅による力に比べて十分に小さいと考え考慮し ないものとした .

式(8)はオイラー法による差分方程式，

$V(t+\Delta t)=V(t)+F(t) / M \Delta t$

$P(t+\Delta t)=P(t)+V(t) \Delta t$

によりシミュレーションする .

ここで，

$V(t):$ 速度べクトル

$P(t)$ : 位置座標ベクトル

である。

\section{4.トンボの飛翔制御法}

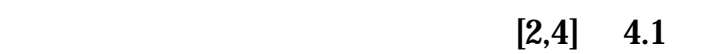
説明し,次にトンボの飛翔制御のための拡張を示す.

\section{1 制御点による制御法}

空間に制御点を配置し，光れを順に通過するよう に昆虫の進行方向と翅のはばたきを制御する。制御 点への到達は, 昆虫力制御点を中心とする一定半径 $r_{p}$ の球体内に入ったときとする .

昆虫のローカル座標系と回転運動を図 15 に示す． $\mathrm{x}$ 軸を回転軸とする回転運動をローリング，y軸を 回転軸とする回転運動をヨーイング， $\mathrm{z}$ 軸を回転軸 とする回転運動をピッチングという .

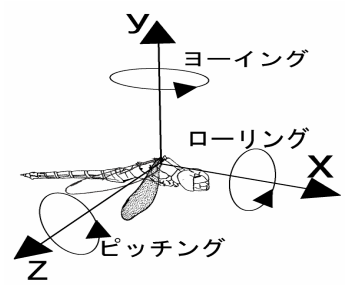

図 15 昆虫のローカル座標系と回転運動

昆虫の頭の向きを表す方向ベクトル ( x 軸に並行 なべクトル) か制御点を向くように, 昆虫の重心を 中心として一定の回転速度でヨーイングとピッチン グを同時に行う.ただし，トンボのピッチング角 (ト ンボの $\mathrm{x}$ 軸とワールド座標系の水平面とのなす角) には，頭部の上がりすぎ，下がりすぎを防ぐため制 限を設けた (7.のシミュレーションでは土 $10^{\circ}$ とし た) .

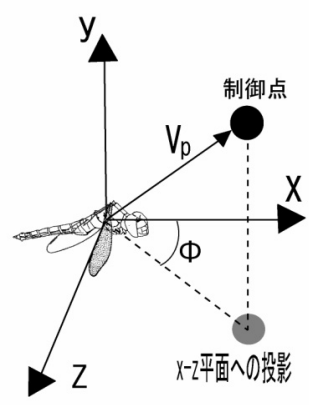

(a)ヨーイングのழ

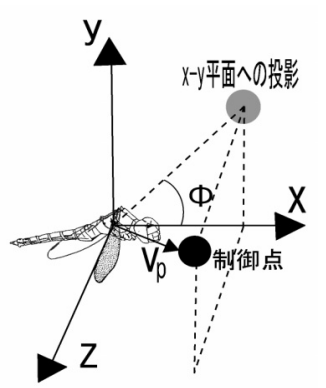

(b)ピッチングの

図 16 回転運動の計算に用いる 
ヨーイング，ピッチングの回転速度いは式(16)で 定義される．

$$
\omega=-\operatorname{sgn}(\varphi) R
$$

ここで， $R$ は基隼回転速度であり， $\operatorname{sgn}$ は $\varphi>0$ とき $+1, \varphi=0$ のとき $0, \varphi<0$ のとき-1の值をとる関数 である .また , ヨーイングのための $\mathrm{x}$ 軸とトンボから制御点へ向かうべクトル $V_{p}$ を $\mathrm{x}-\mathrm{z}$ 平面へ投影したベクトルとのなす角 , ピッチングの ためのり は, トンボの $\mathrm{x}$ 軸と, ベクトル $\mathrm{V}_{\mathrm{p}}$ を $\mathrm{x}-\mathrm{y}$ 平 面へ投影したべクトルとのなす角である (図 16 参 照).

昆虫の高度か制御点より低い場合は，はばたき振 動数を高くしてフラッピング角, フェザリング角を 大きくし, 高い場合は, はばたき振動数を低くして フラッピング角 , フェザリング角を小さくして高度 を調整する。

はばたき振重数 $f$ は次式によって調整する .

$$
f(t+\Delta t)= \begin{cases}f_{\max } & f_{\max }<f(t) \\ f(t)+\operatorname{sgn}\left(y_{p}-y_{i}\right) K_{f} \Delta t & f_{\min } \leq f(t) \leq f_{\text {max }} \\ f_{\text {min }} & f(t)<f_{\text {min }}\end{cases}
$$

ここで, $f_{\text {max }}, f_{\text {min }}$ は光れどれ最大, 最小振動数， $K_{f}$ は1秒間当たりの振重嵝変位量, $y_{p}, y_{i}$ は光れ光れ制 御点と昆虫の $\mathrm{y}$ 座標值である.

はばたきのフラッピング角 , フェザリング角の調 整は, 図8に示したフラッピング, フェザリングの 角度に次式の amp を乗じることにより行う。

$$
\operatorname{amp}(t+\Delta t)= \begin{cases}1 & 1<\operatorname{amp}(t) \\ \operatorname{amp}(t)+\operatorname{sgn}\left(y_{p}-y_{i}\right) K_{a} \Delta t & K_{\min } \leq \operatorname{amp}(t) \leq 1 \\ K_{\min } & \operatorname{amp}(t)<K_{\min }\end{cases}
$$

ここで, $K_{\min }$ は下限値 $\left(0 \leq K_{\min }<1\right), K_{a}$ は1秒間当 たりの変位量である .

\section{2 バンクの導入}

高速に飛翔するトンボでは, 4.1 の制御法のみでは 制御点へ接近できない場合がある. 产の原因の一つ は左右への方向転換をヨーイングに頼ることによる 横滑りである[14] . 横滑りは左右へ胴体を傾けるバ ンクで防ぐことができる[4][14] . バンクは方向 転換したい側の翅を下げるローリング運動である . なお，トンボが必要以上に傾かないようにバンク角
(トンボの $\mathrm{z}$ 軸とワールド座標系の水平面とのなす 角) にも制限を設けた (7.のシミュレーションでは $\pm 24^{\circ}$ とした) .

ローリングの回転速度 $\omega$ を求めるための 17 に示すように, トンボの $\mathrm{z}$ 軸と，ベクトル $V_{p}$ を $\mathrm{y}-\mathrm{z}$ 平面へ投影したべクトルとのなす角である .

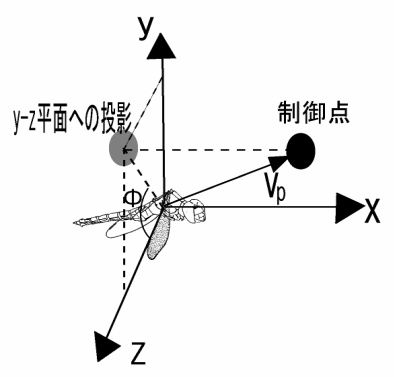

図 17 ローリングの計算に用いる $\varphi$

\section{3 方向転換の回転速度に関する拡張}

ヨーイングやピッチングの回転速度は一定である ため, 制御点同士が近く，かつ, 急な旋回が必要な 場合 , 回転運動か間に合わない場合がある .

このため, 本手法ではヨーイング , ピッチング, ローリングの回転速度いを式(19)で定義した .

$$
\omega=-\operatorname{sgn}(\phi)\left\{R+\left|\frac{\phi}{\pi}\right|^{n}\left(R_{\max }-R\right)\right\}
$$

ここで, $R_{\max }$ は最大回転速度,$n$ は調整用係数 $(n>0)$ である . 方向転換の回転速度は $\varphi$ か大きいほど速く 小さいほど遅くなる。

\section{4 高度制御の拡張}

4.1では,はばたき振動数とフェザリング角 , フラ ッピング角は, 制御点とトンボの高度差によって調 整しているため，高さの異なる制御点間の飛翔は図 18(a)のような経路を描いて飛ぶことになる．トンボ は直線的に飛翔する性質があるため，2つの制御点 を端点とする線分を考え，この線分とトンボとの高 度を比較して高度調整することにした (図 18(b)参 照).

このため, 式(17), (18)の制御点の高度 $y_{p}$ の代わり に次式の $y_{p}{ }^{\prime}$ を用いる .

$$
y_{p}{ }^{\prime}=y_{p}-\left(y_{p}-y_{0}\right) \frac{d_{i}}{d_{p}}
$$

ここで, $y_{0}$ は1つ前の制御点の高度,$d_{p}$ は, 制御点 から 1つ前の制御点までの水平距離， $d_{i}$ は制御点か らトンボまでの水平距離である(図 19参照). 


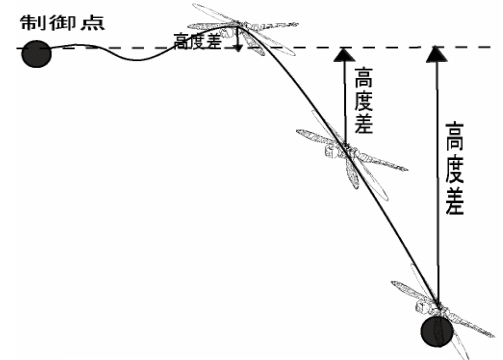

（a） 従来の高度制御

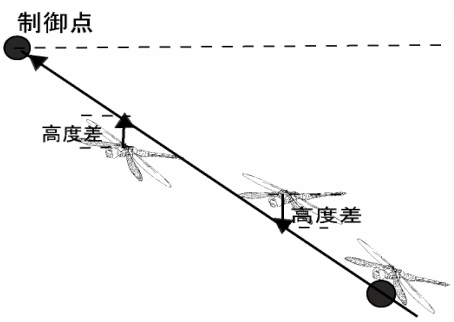

(b) 直線飛行だめ高度制御

図 18 高度制御法

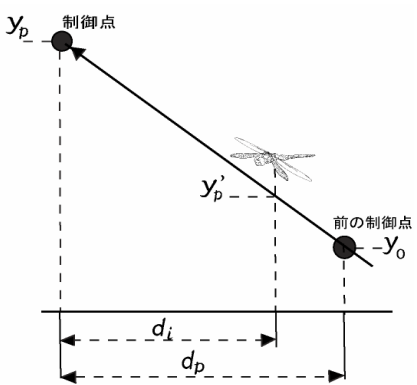

図 $19 y_{p}{ }^{\prime}$ の計算法

\section{5 ホバリングの拡張}

4.1では, はばたきながら空中の一点に静止す るホバリングは考慮されていない . 本手法ではホバ リンク専用の制御点 (ホバリンク制御点) を導入し， この制御点に接近したとき一定の時間ホバリングさ せている.この制御ではホバリンク制御点を中心と する一定半径 $r_{h}\left(r_{p}\right)$ の球体内部にトンボが入っ たとき, ストローク面を大きく傾けることで咸速と 空中静止を行う . ストローク面角度 $\theta$ は次式て計算 する .

$$
\theta(t+\Delta t)= \begin{cases}\theta_{\max } & \theta_{\text {max }}<\theta(t) \\ \theta(t)+\operatorname{sgn}(L(t+\Delta t)-L(t)) K_{s} \Delta t & \theta_{\text {min }} \leq \theta(t) \leq \theta_{\text {max }} \\ \theta_{\text {min }} & \theta(t)<\theta_{\text {min }}\end{cases}
$$

ここで，Lはトンボから制御点までの距離， $\theta$ min ,

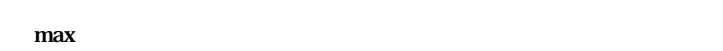
值, $K_{s}$ はストローク面角度の回転速度である.

高度を維持するための，はばたき振動数とフラッ

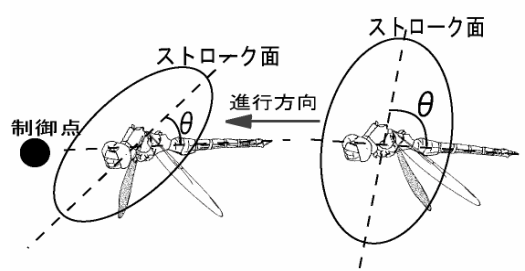

図20 ホバリンク制御

ピング角 , フェザリング角の制御は式(17),(18)によ って行う。

5.トンボの行動の表現

ここでは, 巡航飛翔と止まり方の表現法について 示す.

5. 1 巡航飛翔

トンボは，攁ややなわばり維持のための飛翔を行 う.これを巡航飛翔と呼ぶことにする. 巡航飛翔で はトンボは頻繁に方向を変えているが, 直線的な飛 翔は天敵に進路を予測されやすく，捕食される可能 性か高くなるためではないかと思われる．また，卜 ンボの視覚範囲に新たな目標を発見したとき，進行 方向を変えるためとも考えられる .

4.で示した制御点による制御法では，制御点どう しが遠く離れていてもトンボは光の間を直線的に飛 翔し，実際の飛翔形態とは異なる．本手法では，よ り自然なトンボの飛翔を実現するため, トンボが直 線的に飛翔する距離を数十センチ〜数メートル程度 に制限する . 制御点間がこの距離より離れている場 合は，図21に示すように副制御点を生成し，直線的 に飛翔する距離を抑える。

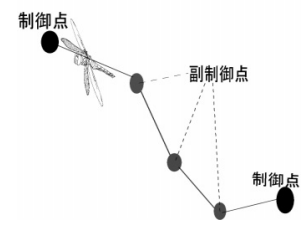

図 21 副制御点の生成

副制御点の生成は图 22 に示すように，まず，最初 に出発点の制御点から目標点の制御点へ向かうべク トルを求め, 兴のベクトルを中心軸として高さ $h$, 頂角 $2 \Psi$ の円錐体の底面内に副制御点を1つ(副制 御点1) 発生させる.次に, 副制御点1から目標点 の制御点へ向かうベクトルを求め, 同樣の方法て副 制御点 2 を求める.この操作を, 最後に求めた副制 御点と, 目標点の制御点との距離がん以下になるま て繰り返す . なお, $h$ および $\psi$ は式(22), (23)で求め る。 


$$
\begin{aligned}
h & =\left(h_{\max }-h_{\min }\right) r n d+h_{\min } \\
\Psi & =\left(\Psi_{\max }-\Psi_{\min }\right) r n d+\Psi_{\min }
\end{aligned}
$$

ここで, $h_{\text {max }}, h_{\min }$ および $\Psi$ max, $\Psi$ min はとれ光れ， hの最大最小值 , $\Psi$ の最大最小值であり, rndは 0 1 の一樣乱数である.

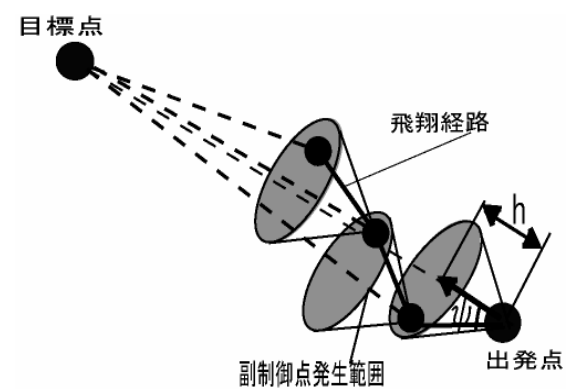

図 22 副制御点の生成法

\section{2 止まり方の表現}

トンボの止まり方には「うつう池型」と「ぶら下 がり型」の2つがある . うつう池型では，とまり先 の上で咸速してから降下して着地し，ぶら下がり型 では, とまり先へ横から接近し, 減速してから止ま る.

4 .の制御点による制御法では, 真つ直ぐ制御点に 到達するため, 止まる場所の上や横から接近させる ことができない場合がある．このため，うつゔ型 では, 図 23(a)のように, 止まり制御点の上に副制御 点を1つ発生させ, 止まり点の上の副制御点を通過 してから止まり点に達するようにしている . 止まり 点では,ホバリングと同樣のストローク面の制御(た だし , 式(21)の $く$ はンンボら制御点までの水平距 離とする) を行いトンボの高度が止まり点の高度ま で降下したとき停止させている．また，「ぶらら下がり 型」では, 図 23(b)のように, 止まり制御点の手前に 副制御点を1つ発生させ，この制御点を経由して， 止まり点へ向かわせている . 止まり点ではホバリン グと同樣の制御を行うが, 式(21)の $\theta$ min をホバリン ク時より大きく設定することで , (空中静止すること なく) ゆっくり止まり点へ接近させている .

\section{6. 複数のトンボの飛翔}

トンボごとに制御点列を与えることで , 複数のト ンボを同時に飛翔させることができる．このとき， トンボ同士が衝突しないようにBoid[3]で用いられ たような衝突回避運動を行う.

図 24 では, 注目するトンボか中心に位置している ものとしている . 注目するトンボの半径 $r$ の領域内

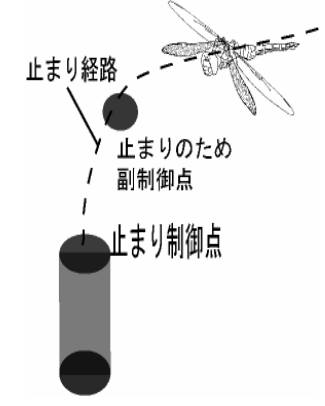

(a) うつょ池型

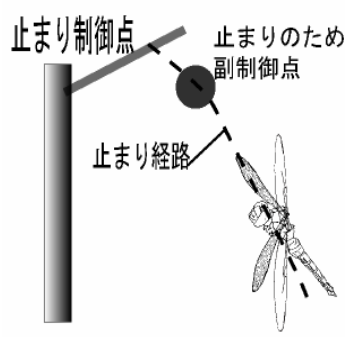

(b)ぶら下がり型
図23止まり制御法

に他のトンボが入ってきたとき，中心のトンボから 領域内のすべてのトンボへの相対ベクトル Qを求め， 式(24)より衝突回避べクトル $V_{c a}$ を求める .

$$
V_{c a}=-\Sigma Q_{i}\left(1-\left|Q_{i}\right| / r\right)
$$

4.て述べたトンボから制御点へ向かうベクトルを $V_{p}$ とすると, 衝突回避を考慮した方向べクトル $V_{p}^{\prime} を$ 式(25)で求める .

$$
\mathrm{V}_{\mathrm{p}}^{\prime}=\mathrm{V}_{\mathrm{p}}+\mathrm{V}_{\mathrm{ca}}
$$

Vマを $V_{P}$ の代わりに用いることによりトンボに回避 行動を行わせる．なお，この制御によりトンボか制 御点に到達できなくなる状況も考えられる .このた め, 制御点に到達するための試行回数を制限するこ とにした .すなわち，指定された試行回数を超えた 場合は，弚の制御点を飛ばして次の制御点へ向かわ せている。

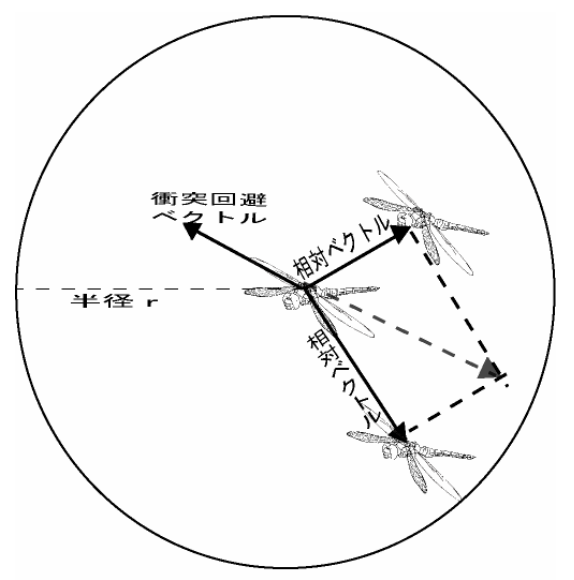

図 24 衝突回避ベクトル

7.トンボの飛翔シミュレーション結果 SGI OCTANE2 (R12000 1.4GHz , RAM512MB) 
を使用し，計算刻み幅を 1/12000 秒としてはばたき の力を計算した .表示にはOpenGL を使用し , トン ボ1匹の場合は毎秘約 70 フレームで表示すること ができた .なお，トンボの形状はミヤマアカネ (赤 トンボの一種) を参考に定義した .

図 25 に制御点による飛羭㹩絡の制御例を示す.图 中の破線はトンボの飛翔経路を表し, 球は制御点を 表している.制御点間をまっすぐ飛翔していること がわかる。

図 26 は巡航飛翔の例である.図 25 とは異なり， 制御点間をジグザグに進んていることがわかる .

図 27 に止まりの例を示す . (a)はうつう汹型，(b) はょらら「が型の例である.うつう汹型では上から， ぶら下がり型では横から接近しているようすがわか る。

図 28 に複数のトンボのシミュレーション例を示 す. 6 匹のトンボが衝突を回避しながら同時に飛翔 している.図29に, 背景に風景写真を貼り付けた動 画像の抜粋を示す .なお，止まりのシミュレーショ ンと複数のトンボの飛翔の動画像, およびホバリン グのスローモーションを MPEG ファイルとして添 付した。

\section{8. むすび}

空気力学に基づくトンボの飛翔モデルを提案した . 本モデルでは翅のはばたきによる力を計算し, リア ルタイムでトンボの飛翔を表現することができる . トンボの飛翔の特徵である急上昇，急停止 , ホバリ ング , 急旋回などの飛翔形態の表現か可能であり， トンボの飛羘桼路を容易に設定することかで゙る．

今後の課題としては, 求愛行動やなわばり維持行 動の表現 , 補食行動の表現法などの開発力学げられ る.また , 仮想網によるトンボ捕獲のシミュレーシ ヨン法の開発なども興味深い .

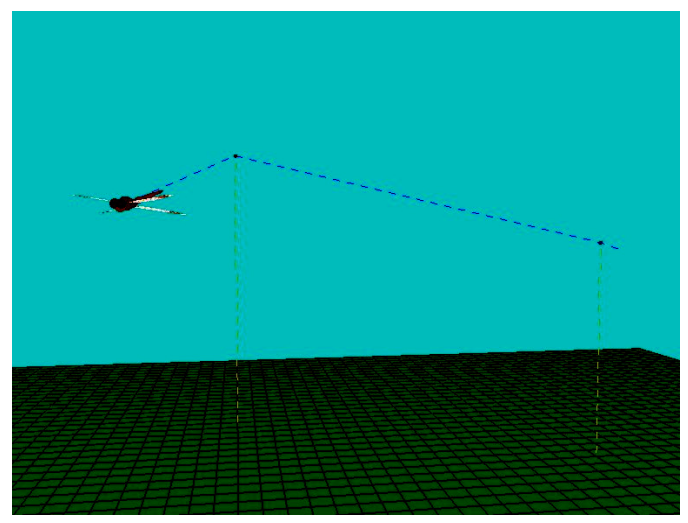

図 25 制御点による飛翔経路

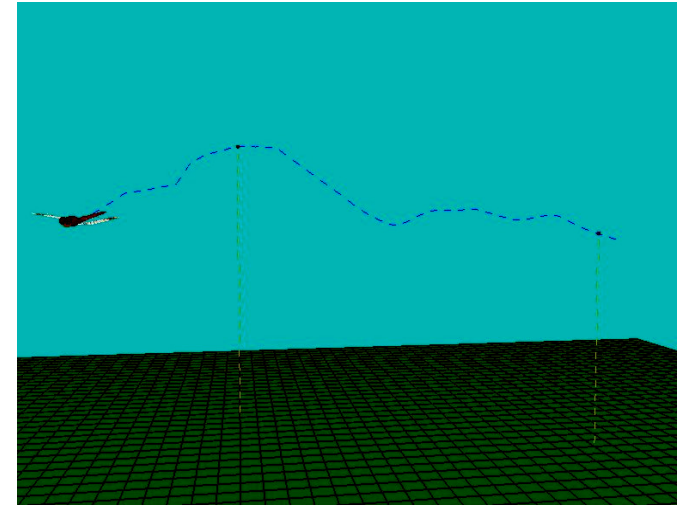

図26 巡航飛翔の例

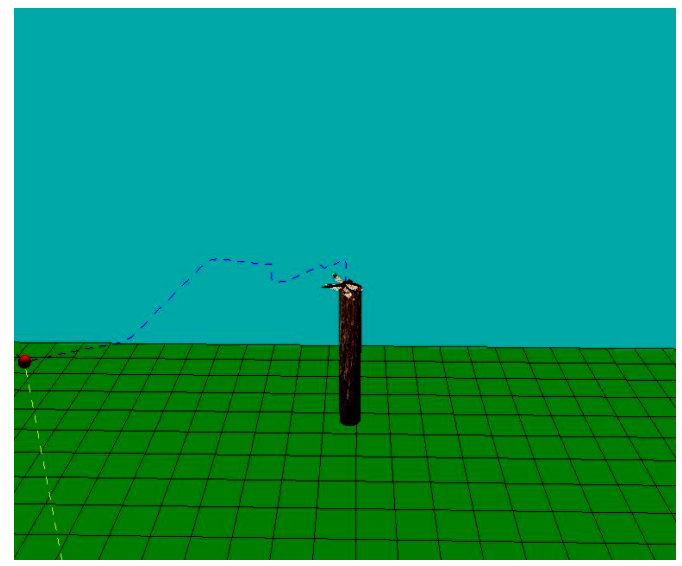

(a)うつふ汹型

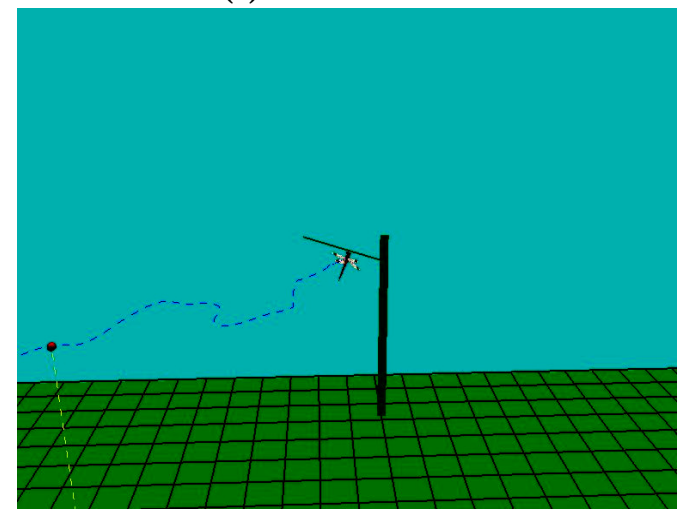

(b)ぶら下がり型

図 27 止まりのシミュレーション

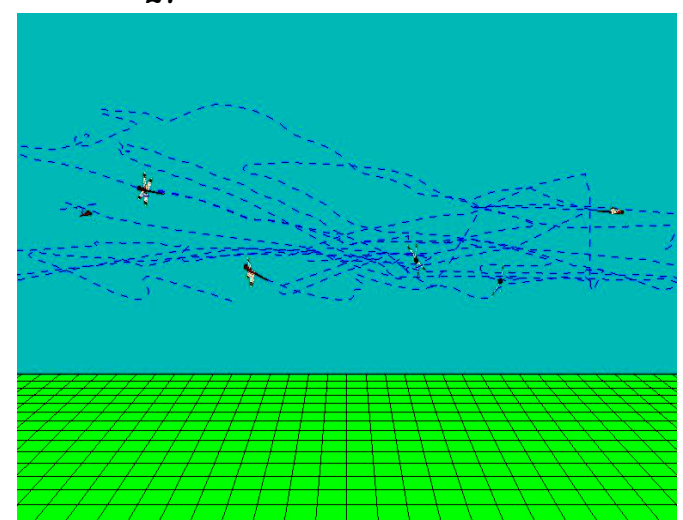

図 28 複数のトンボの飛翔シミュレーション 


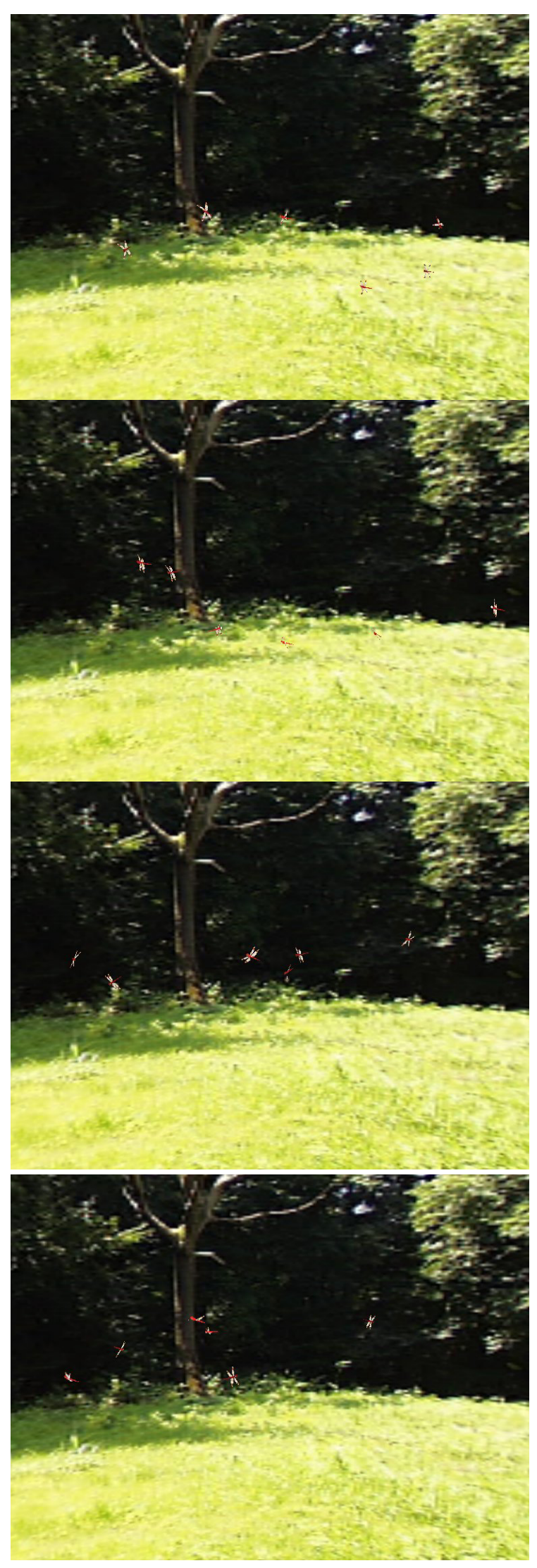

図 29 複数のトンボの飛翔の動画像の抜粋 謝辞＼cjkstart熱心にこ討論していただき，貴重なこ意見を いただきました東北工業大学斎藤伸自名誉教授，な らびに岩手大学工学部千葉則茂教授に感射いたしま す。また，本研究を開始するにあたり，こ助言いた だきました有限会社ピー・ソフトハウスの安齋祐一 氏に感射いたします．

\section{参考文献}

[1] 雨川浩之 , 武内良三 : コンピュータアニメーションにおける行 重㫼御の一手法, 第4回 NICOGRAPH 論文集 , pp. 98-103 (1988).

[2] 安齋祐一, 村岡一信, 千葉則茂, 齋藤伸自 : 翅のはばたきによ る力を考慮した蝶の飛翔モデル, 情報処理学会論文誌, Vol.41 No3, pp. 658667 (2000).

[3] C.W.Reynolds:Flocks,Herds,and Schools:A Distributed Behavioral Model, SIGGRAPH,Vo21,Number4 , pp. 25- 34 (1987).

[4] 曹 燦, 藤本忠博, 村岡一信, 千葉則茂: 鳥の飛翔のビジュア ルシミュレーション, 第 17 回 NICOGRAPH 論文集, pp. 93. 98 (2001).

[5] B.Ramakrishnananda and K.C.Wong: Animating bird flight using aerodynamics, The Visual Computer,Vo15,Number10, pp. 494508 (1999).

[6] 井上清 , 谷幸三 : トンボのすべて , トンボ出版 (1999).

[7] A.Azuma: FLIGHT MECHANICS OF A DRAGONFLY, J .exp.Biol.116, pp.79-107 (1985).

[8] アンドレイ K.ブロドスキイ : 昆蚓飛翔のメカニズムと進化， 築地書館 (1997).

[9] 東 昭: 生物・㶢の素晴らしい動き, 共立出版 (1986).

[10] R.マクニール・アレクサンダ- : 生物と運動 バイオメカニ ックスの探求 , 日経サイエンス社 (1992).

[11] 新井 裕 : トンボの不思議, どううつ社 (2000).

[12] 東 昭 : 生物の動きの事典, 朝倉書店 (1997).

[13] 学研の図鑑 昆虫 (1997).

[14] 東 昭: 機械工学選書 航空工学 (I) - 航空流体力学, 裳華 房 (1998).

[15] M.Didkinson: 昆虫飛翔の空気力学, 日経サイエンス，pp. 46- 54 ( 2001. 9)

[16] 劉 浩, 河内啓二 : 昆虫ホバリングに関する数値解析 , 日本 機械学会第 74 期全国大会講演論文集(I),pp. 231 - 232 (1996). 